\title{
Study of the Copper, Chromium, Manganese and Zinc Contents in the Species Azorella spinosa (Apiaceae), Collected in the Maule Region, Chile
}

\author{
Jaime Tapia ${ }^{1 *}$, Jorge Cornejo ${ }^{1}$, Margarita Gutiérrez ${ }^{*}$, Patricio Peñailillo², Ricardo Baettig3,

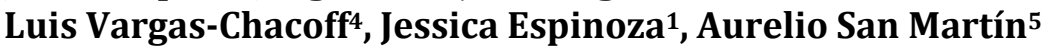 \\ ${ }^{1}$ Institute of Natural Resources Chemistry, University of Talca, Talca, Chile \\ ${ }^{2}$ Institute of Biological Sciences, University of Talca, Talca, Chile \\ ${ }^{3}$ Faculty of Forestry Sciences, University of Talca, Talca, Chile \\ ${ }^{4}$ Institute of Marine Science and Limnology, University Austral of Chile, Valdivia, Chile \\ ${ }^{5}$ University of Magallanes, Punta Arenas, Chile \\ Email: ^jtapia@utalca.cl, ^mgutierrez@utalca.cl
}

How to cite this paper: Tapia, J., Cornejo, J., Gutiérrez, M., Peñailillo, P., Baettig, R., Vargas-Chacoff, L., Espinoza, J. and Martín, A.S. (2019) Study of the Copper, Chromium, Manganese and Zinc Contents in the Species Azorella spinosa (Apiaceae), Collected in the Maule Region, Chile. Journal of Environmental Protection, 10, 601-613. https://doi.org/10.4236/jep.2019.105035

Received: February 27, 2019

Accepted: May 7, 2019

Published: May 10, 2019

Copyright ( 2019 by author(s) and Scientific Research Publishing Inc. This work is licensed under the Creative Commons Attribution International License (CC BY 4.0).

http://creativecommons.org/licenses/by/4.0/

\begin{abstract}
The increase in prevalence of environmental pollution, especially soil contamination with toxic metals has led to their uptake in the human food chains through plant parts. Accumulation and magnification of heavy metals in human tissues through comsuption of herbal medicine can cause hazardous impacts on health. Therefore, chemical profiling of four heavy metals $(\mathrm{Cu}, \mathrm{Cr}$, $\mathrm{Mn}$ and $\mathrm{Zn}$ ) was undertaken in samples of Azorella spinosa from coast and mountain of Maule Region in Chile. The $\mathrm{Cu}, \mathrm{Cr}, \mathrm{Mn}$ and $\mathrm{Zn}$ concentrations were determined in plants of the species Azorella spinosa and their soils of origin. For each plant, the metal contents in the stalk, leaves and soil were determined by flame atomic absorption spectroscopy. The methodology was validated using certified reference material: BIMEP-432 for the plant samples and MESS- 1 for the soil samples. The concentration ranges found in the plant tissue were: $\mathrm{Cu}: 1.2$ - 62.5; Cr: 0.2 - 3.2; Mn: 188.6 - 1345.1 and $\mathrm{Zn}: 7.5$ - 55.9 $\mathrm{mg} \cdot \mathrm{kg}^{-1}$ (dry weight). For the soil samples, the ranges were: $\mathrm{Cu}$ : $6.4-81.5$; $\mathrm{Cr}$ : 4.6 - 50.4; Mn: 335.6 - 1936.1 and $\mathrm{Zn}: 15.6$ - $65.9 \mathrm{mg} \cdot \mathrm{kg}^{-1}$ (dry weight). The results were evaluated statistically (two-way ANOVA) to correlate the $\mathrm{Cu}, \mathrm{Cr}$, $\mathrm{Mn}$ and $\mathrm{Zn}$ concentrations in Azorella spinosa plant tissues with those in the soil samples from the corresponding sampling areas.
\end{abstract}

\section{Keywords}

Azorella spinosa, Toxic Metals, Atomic Absorption, Maule Region 


\section{Introduction}

Medicinal plants have been used for many years to prevent and control different types of diseases and pains. Medicinal plants are an important element of traditional medicine and are used increasingly in primary health care interventions in different countries around the world [1] [2]. In many cases, these medicinal herbs are used when the disease is considered to be a loss of physical, emotional and spiritual condition [3]. According to estimates by the World Health Organization (WHO), around $70 \%-80 \%$ of the world's population still depends principally on non-conventional medicines, the majority derived from herbaceous plants [4] [5] [6]. Medicinal herbs contain very active pharmacological components, which include a wide variety of minerals and toxic metals in different concentrations [7].

The safety and quality of medicinal herbs are affected by different factors. These may be intrinsic, change for as differences between species, or extrinsic, depending on the environment or on collection, cultivation, harvesting, post-harvest treatment, transport and storage methods and practices. The properties and characteristics of a medicinal plant may depend significantly on the medium in which it grows, due to other variables such as soil characteristics, the geography of the land, the presence of agrochemicals, and the water and air in the environment [8] [9].

In general, plants are extremely sensitive to environmental conditions and can accumulate certain contaminants, affecting their growth and development. A plant may absorb contaminants through its roots, stem and leaves, including by direct deposition from the air of certain specific elements or compounds on the plant surfaces. Consumption of medicinal plant products contaminated with toxic metals above certain concentrations produces harmful effects in most living organisms [10].

Some toxic metals, such as copper, chromium, iron, manganese and zinc, are considered essential elements for the growth and development of the human body, since they play an important role in certain physiological and biological functions. However, above a certain level their presence may harm human health [11] [12]. In general, a series of health problems are related with excessive absorption of toxic metals in diet, including debilitation of the immune system, cardiac disease, fatal malformation, deterioration of psychosocial and neurological behaviour, gastrointestinal cancer, etc. [10].

Due to the remove potentially toxic effects in humans of the consumption of medicinal plants as a primary health care treatment, it is vital to know the concentrations of certain metals, considering principally the species, its soil of origin, its geographical location and the surrounding medium [10]. Contamination of medicinal herbs by toxic metals has previously been reported in various plant-based products in different countries [13] [14] [15].

Azorella Lam. is a genus of the Apiaceae (Umbelliferae) represented by 70 species which grow in South America, New Zealand, Australia and Islands of 
Southern Ocean. In Chile it is commonly known as "yareta"; these species are distributed from the tropical high Andes in the north to Tierra del Fuego in the south. In traditional medicine it is used by the indigenous population as a gastric stimulant in the form of an aqueous infusion. Many extracts and infusions are diuretic and analgesic, effective against migraine, neuralgia, pneumonia and rheumatism [16]. These species are known to have unique diterpenoid structures, such as skeletons of mulinane and azorellane, for which a wide range of biological activities have been reported [17] [18].

In the present investigation, we determined the concentrations of $\mathrm{Cu}, \mathrm{Cr}, \mathrm{Mn}$, and $\mathrm{Zn}$ in the species A. spinosa and its soils of origin. The samples analysed were collected in the coastal and mountain zones of the Maule Region, Chile. The object of this study was to determine whether the concentrations of $\mathrm{Cu}, \mathrm{Cr}$, $\mathrm{Mn}$ and $\mathrm{Zn}$ in $A$. spinosa is within the levels permitted by current legislation [19] [20], and whether the consumption of this plant is a potential health risk for consumers.

\section{Materials and Methods}

\subsection{Study Area}

Samples of soils and plants of $A$. spinosa were collected in 2015. The study area consisted of two zones located in the Maule Region, Chile. The first were collected during January of 2015 in Pantanillo, near Constitution in Maule Region of Chile (geographical coordinates $35^{\circ} 43^{\prime}$ and $35^{\circ} 47^{\prime}$ south latitude; $72^{\circ} 29^{\prime}$ and $72^{\circ} 31^{\prime}$ west longitude), located in the coastal sector, where 13 sampling sites were selected. The second samples was collected during March of 2015 in Vilches, near of San Clemente in Maule Region of Chile (geographical coordinates $35^{\circ} 32^{\prime}$ south latitude; $71^{\circ} 50^{\prime}$ west longitude), in the district of San Clemente, located in the mountain sector, where 8 sampling sites were selected. Figure 1 shows the geographical location of the two study zones. A voucher specimen was deposited in the herbarium of University of Talca (Voucher $n^{\circ} 3360$ ), Talca, Chile.

\subsection{Sample Collection}

The species $A$. spinosa was identified in the coastal and cordillera study zones and samples of the aerial parts of the plant were collected (leaves and stems). The samples were labelled and kept in plastic containers for subsequent chemical analysis. The soil samples were collected by digging test trenches to a depth of 10 $\mathrm{cm}$. and extracting soil with PVC materials. The samples were labelled and kept in plastic containers for subsequent chemical analysis.

\subsection{Chemical Analysis}

The plant samples (leaves and stalks) were washed with bi-distilled water and dried in a stove at $105^{\circ} \mathrm{C}$ to constant weight. They were then milled and homogenised and $1.0 \mathrm{~g}$ of plant tissue was weighed out and calcinated slowly in a por 


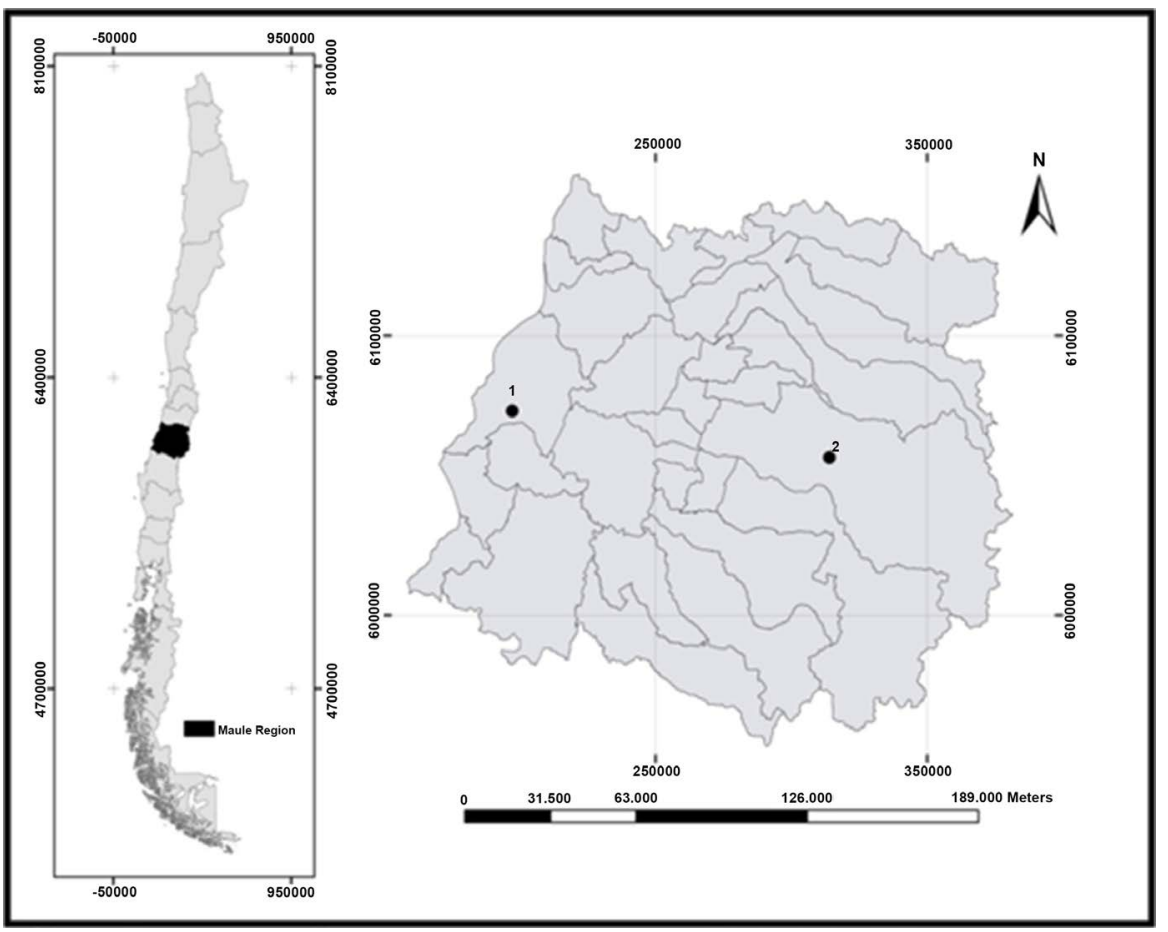

Figure 1. Location of the coastal (1) and mountain (2) study zones where samples of $A$. spinosa were collected in the Maule Region, Chile.

celain crucible to reach a temperature of $500^{\circ} \mathrm{C}$ over 4 hours. Blank solutionswere also included. The crucibles were allowed to cool to room temperature and $2 \mathrm{~mL}$ of bi-distilled water and $10 \mathrm{~mL}$ of nitric acid p.a. were added. The solutions were heated on a heating plate with constant stirring until almost dry. They were then filtered using $0.45 \mu \mathrm{m}$ porosity filters. The filtrate was augmented to a final volume of $50 \mathrm{~mL}$ with bi-distilled water [21] [22].

The soil samples were dried at $105^{\circ} \mathrm{C}$. A representative sample of $0.5 \mathrm{~g}$ of soil was mixed with $50 \mathrm{~mL}$ of a mixture of $\mathrm{HF}-\mathrm{HNO}_{3}(2: 1)$ was then solubilized at $120^{\circ} \mathrm{C}$ until almost dry, with constant stirring. The resulting solution was filtered using $0.45 \mu \mathrm{m}$ filter porosity and then washed with bi-distilled water, and made up to a final volume of $50 \mathrm{~mL}$ in a pre-treated volumetric flask. The analyses were performed in front of their respective control solutions [23] [24].

The reagents used were of high purity (Suprapur, Merck, Darmstadt, Germany). The standard solutions for the various metals were prepared from concentrated solution of the metal of $1000 \mathrm{mg} \cdot \mathrm{L}^{-1}$, (Fisher Scientific International Company). Cleanliness of the material was fundamental to guarantee optimum results in analysis. The metal measurements were done by Flame Atomic Absorption Spectroscopy (air/acetylene), using a Unicam spectrophotometer mod. 969

\subsection{Validation Methodology}

The plant analysis methodology for quantification of $\mathrm{Cu}, \mathrm{Cr}, \mathrm{Mn}$ and $\mathrm{Zn}$, was validated using certified reference material BIMEP-432, supplied by the Wagen- 
ingen Evaluating Programs for Analytical Laboratories (WEPAL). The soil analysis methodology for determination of concentration of $\mathrm{Cu}, \mathrm{Cr}, \mathrm{Mn}$ and $\mathrm{Zn}$ was validated using certified reference material MESS-1, supplied by the National Research Council, Canada, (NRC), Division of Chemistry.

\subsection{Statistical Analysis}

Two-way ANOVA was performed to compare the metal concentrations in the different sampling zones (coastal and cordillera), considering the plant and soil matrices in each sampling site. Where there were significant differences, Tukey's Test was carried out subsequently. First, the assumptions of the ANOVAS were tested (normality, homoscedasticity and independence); when none of the assumptions was met, the data were transformed by $\log (\mathrm{x})$. The level of significance used was 0.05 .

\section{Results and Discussions}

Atmosphere and soil are continuously being polluted with chemicals and toxic metals due to dynamic development of industries and motorization along with extensive use of pesticides and fertilizers. In turn, these pollutants and toxic metals are getting deposited in the plants growing in the polluted areas, which subsequently enter the human food chain via plant parts and/or extracts. Results of analysis of four toxic metals ( $\mathrm{Mn}, \mathrm{Cr}, \mathrm{Cu}$ and $\mathrm{Zn}$ ) done in soil and plats of $A$. spinosa are study in this work.

The samples of Azorella were collected in the zones of the coast and mountain of the region of Maule due to their abundance in these zones, in order to compare the presence and the absorption of metals in the samples of soil and plants. Thus, it is possible to compare different types of soil and different anthropic activities at the sampling sites. The metals were selected on the basis of a background of previous research [24] [25] where it is observed the accumulation of these metals in marine organisms and lichens of the Maule region.

\subsection{Certified Reference Material, Samples and Their Soils of Origin}

Table 1 and Table 2 show the results of the $\mathrm{Cu}, \mathrm{Cr}, \mathrm{Mn}$ and $\mathrm{Zn}$ measurements in the reference materials BIMEP-432 and MESS-1, corresponding to plant tissue and soil respectively. The replicated measurements showed good accuracy, with relative errors for plant tissue ranging between $1.8 \%(\mathrm{Mn})$ and $27.8 \%(\mathrm{Cu})$. For soil the relative errors ranged between $1.7 \%(\mathrm{Cr})$ and $5.9 \%(\mathrm{Zn})$.

The use of certified material allows validating the methodology, considering minimum variations to those reported in the certified samples used.

The general results obtained for the samples of the plant and the soil in the collection areas are summarized in Table 3 , in the mountain area less data are shown due to the difficult access to the sampling area, working only 8 collection sites for the samples coming from this sector.

Figure 2 and Figure 3 show the different levels of the metals analyzed in the two collection zones with their respective statistical analyzes. 
Table 1. Concentration of $\mathrm{Cu}, \mathrm{Cr}, \mathrm{Mn}$ and $\mathrm{Zn}\left(\mathrm{mg}^{\mathrm{kg}} \mathrm{kg}^{-1}\right)$ in certified reference material (BIMEP-432), from the Wageningen Evaluating Programs for Analytical Laboratories (WEPAL).

\begin{tabular}{|c|c|c|c|c|}
\hline Element & Certified Concentration (MAD) & Observed Concentration $(\mathrm{n}=3)$ & Rel. Error (\%) & Recovery (\%) \\
\hline $\mathrm{Cu}$ & $\begin{array}{c}6.05(3.50) \\
(n=6)\end{array}$ & $7.73 \pm 0.98$ & 27.8 & +127.8 \\
\hline $\mathrm{Cr}$ & $\begin{array}{c}2.35(1.65) \\
(\mathrm{n}=4)\end{array}$ & $2.81 \pm 0.80$ & 19.6 & +119.6 \\
\hline $\mathrm{Mn}$ & $\begin{array}{c}20.0(4.00) \\
(\mathrm{n}=5)\end{array}$ & $20.35 \pm 0.86$ & 1.8 & +101.8 \\
\hline $\mathrm{Zn}$ & $\begin{array}{c}18.5(2.80) \\
(\mathrm{n}=6)\end{array}$ & $17.10 \pm 1.33$ & 7.6 & -92.4 \\
\hline
\end{tabular}

MAD: Median of absolute deviation.

Table 2. Concentration of $\mathrm{Cu}, \mathrm{Cr}, \mathrm{Mn}$ y $\mathrm{Zn}\left(\mathrm{mg} \cdot \mathrm{kg}^{-1}\right)$ in certified reference material (MESS-1) from National Research Council Canada (NRC).

\begin{tabular}{ccccc}
\hline Element & Certified Concentration & Observed Concentration $(\mathrm{n}=2)$ & Rel. Error (\%) & Recovery $(\%)$ \\
\hline $\mathrm{Cu}$ & $25.1 \pm 3.8$ & $25.9 \pm 2.4$ & 3.2 & +103.2 \\
$\mathrm{Cr}$ & $71.0 \pm 11$ & $69.8 \pm 3.7$ & 1.7 & -98.3 \\
$\mathrm{Mn}$ & $513 \pm 25$ & $496.1 \pm 18$ & 3.3 & -96.7 \\
$\mathrm{Zn}$ & $191 \pm 17$ & $202.2 \pm 19$ & 5.9 & +105.9 \\
\hline
\end{tabular}

Table 3. Concentrations of $\mathrm{Cu}, \mathrm{Cr}, \mathrm{Mn}$ and $\mathrm{Zn}\left(\mathrm{mg} \cdot \mathrm{kg}^{-1}\right)$ in plants and soils from coastal area and mountain zone of the Maule Region, Chile.

\begin{tabular}{|c|c|c|c|c|c|c|c|c|c|}
\hline & \multicolumn{9}{|c|}{ Maule Region } \\
\hline & & & & ange & & & Pre-m & Range & \\
\hline \multicolumn{2}{|c|}{ Sample } & $\mathrm{Cu}$ & $\mathrm{Cr}$ & $\mathrm{Mn}$ & $\mathrm{Zn}$ & $\mathrm{Cu}$ & $\mathrm{Cr}$ & $\mathrm{Mn}$ & $\mathrm{Zn}$ \\
\hline \multirow{2}{*}{ Site 1} & Plant & 8.7 & 0.2 & 188.6 & 7.5 & 10.7 & 2.2 & 425.7 & 38.6 \\
\hline & Soil & 40.3 & 23.0 & 647.8 & 32.3 & 32.7 & 20.3 & 1936.1 & 65.7 \\
\hline \multirow{2}{*}{ Site 2} & Plant & 7.0 & 0.3 & 238.1 & 27.2 & 14.1 & 2.6 & 404.4 & 15.5 \\
\hline & Soil & 13.2 & 18.0 & 415.9 & 38.9 & 29.4 & 16.8 & 1923.1 & 60.4 \\
\hline \multirow{2}{*}{ Site 3} & Plant & 7.1 & 0.9 & 229.4 & 55.9 & 9.8 & 2.0 & 698.8 & 40.1 \\
\hline & Soil & 13.4 & 19.1 & 389.7 & 32.0 & 18.2 & 10.5 & 563.1 & 65.9 \\
\hline \multirow{2}{*}{ Site 4} & Plant & 6.0 & 0.7 & 511.2 & 26.1 & 13.7 & 2.2 & 788.8 & 25.8 \\
\hline & Soil & 10.1 & 16.1 & 451.1 & 19.0 & 12.2 & 4.6 & 467.3 & 46.2 \\
\hline \multirow{2}{*}{ Site 5} & Plant & 62.5 & 0.7 & 414.0 & 24.2 & 5.0 & 2.7 & 277.4 & 34.0 \\
\hline & Soil & 73.1 & 18.2 & 411.4 & 15.6 & 18.6 & 13.4 & 922.0 & 46.6 \\
\hline Site 6 & Soil & 6.4 & 40.0 & 391.1 & 27.2 & 81.5 & 14.8 & 525.6 & 41.4 \\
\hline \multirow{2}{*}{ Site 7} & Plant & 6.6 & 1.2 & 456.3 & 28.5 & 7.6 & 2.5 & 658.9 & 32.7 \\
\hline & Soil & 7.0 & 36.0 & 384.0 & 28.0 & 21.0 & 9.4 & 380.0 & 41.3 \\
\hline \multirow{2}{*}{ Site 8} & Plant & 6.9 & 3.2 & 799.2 & 35.3 & 6.3 & 1.8 & 390.2 & 28.0 \\
\hline & Soil & 16.7 & 50.4 & 613.4 & 35.2 & 28.7 & 7.6 & 335.6 & 32.0 \\
\hline \multirow{2}{*}{ Site 9} & Plant & 1.2 & 1.5 & 1345.1 & 54.6 & \multirow{2}{*}{-} & \multirow{2}{*}{-} & \multirow{2}{*}{-} & \multirow{2}{*}{-} \\
\hline & Soil & 7.2 & 25.8 & 593.2 & 27.5 & & & & \\
\hline \multirow{2}{*}{ Site 10} & Plant & 23.7 & 2.6 & 323.1 & 16.7 & \multirow{2}{*}{-} & \multirow{2}{*}{-} & \multirow{2}{*}{-} & \multirow{2}{*}{-} \\
\hline & Soil & 40.7 & 39.5 & 352.3 & 26.1 & & & & \\
\hline \multirow{2}{*}{ Site 11} & Plant & 27.7 & 1.6 & 387.7 & 13.7 & \multirow{2}{*}{-} & \multirow[b]{2}{*}{-} & \multirow{2}{*}{-} & \multirow{2}{*}{-} \\
\hline & Soil & 38.6 & 38.7 & 367.0 & 21.7 & & & & \\
\hline \multirow{2}{*}{ Site 12} & Plant & 10.2 & 1.7 & 348.7 & 26.7 & \multirow{2}{*}{-} & \multirow{2}{*}{-} & \multirow{2}{*}{-} & \multirow{2}{*}{-} \\
\hline & Soil & 17.5 & 26.3 & 400.8 & 32.8 & & & & \\
\hline Site 13 & Plant & 60.1 & 2.6 & 913.1 & 28.0 & & & & \\
\hline
\end{tabular}



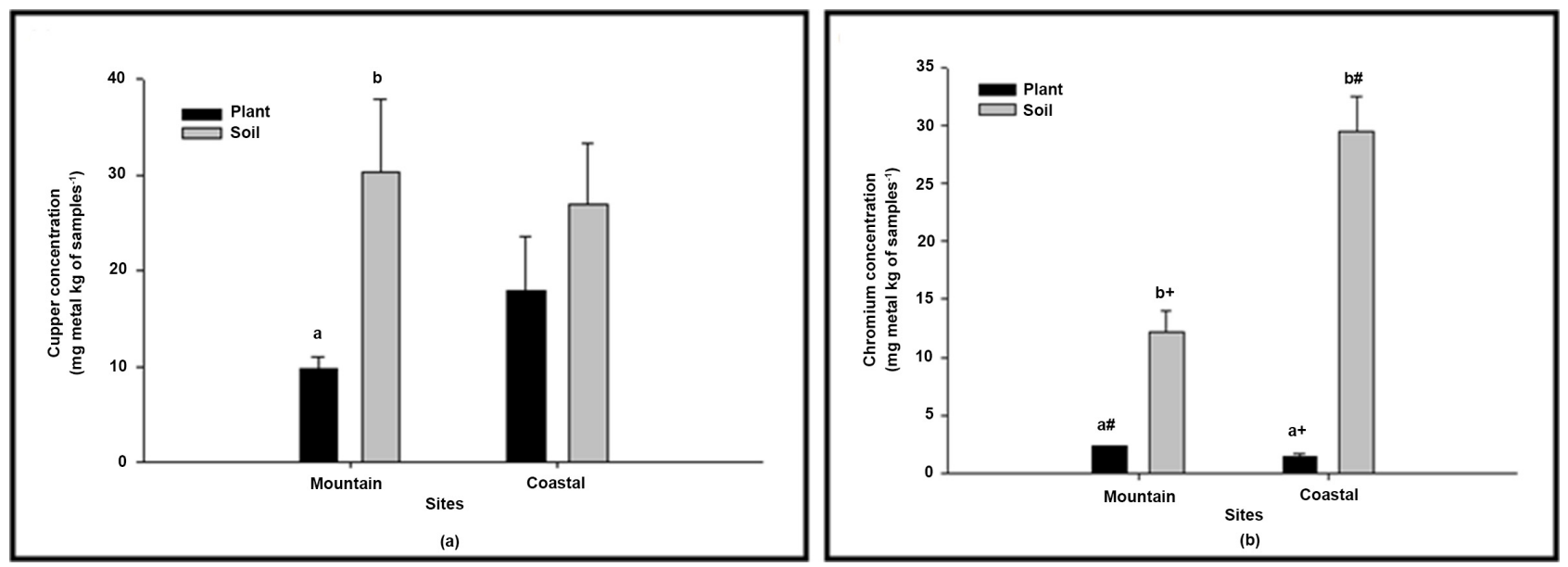

Figure 2. Concentrations of copper (a) and chromium (b) in plant and soil samples collected in the coastal and mountain zones of the Maule Region, Chile. The statistical study $(\mathrm{P}<0.05$, two-way ANOVA, Tukey's test $)$ indicates whether or not there were significant differences between the plants and soils of the same site.
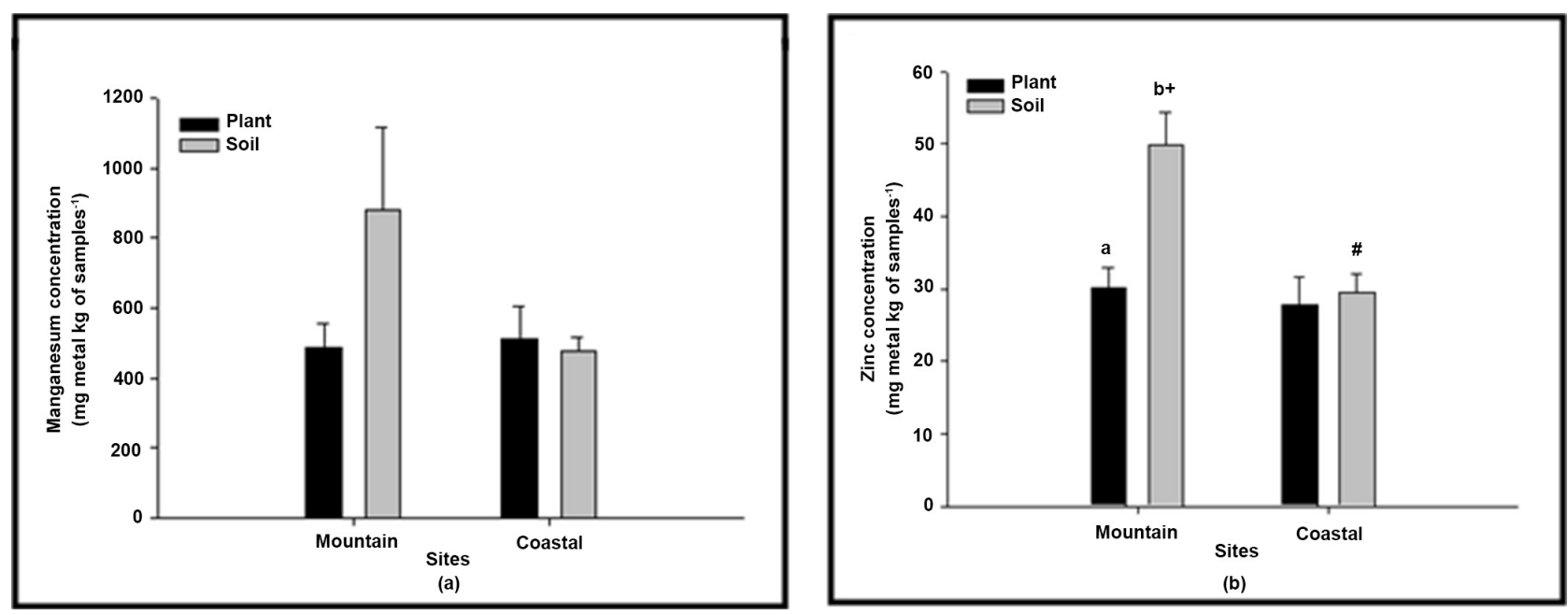

Figure 3. Concentrations of manganese (a) and zinc (b) in plant and soil samples collected in the coastal and mountain zones of the Maule Region, Chile. The statistical study ( $\mathrm{P}<0.05$, two-way ANOVA, Tukey's test) indicates whether or not there were significant differences between the plants and soils of the same site.

In the light of the World Health Organisation's (WHO) data, the percentage of people using medicinal plants is $70 \%-80 \%$ [4]. Herbal raw materials (leaves, herbs, rhizomes, roots, oils) can be sources of undesirable toxic components, including toxic metals. Trace elements, which are essential nutrients and unavoidable constituents of food, are expressed by a range, with the lower end is the minimum daily dietary requirement and the upper end the daily limit, for example, the range for copper is $0.05 \mathrm{mg} / \mathrm{kg}$ b.w. to $0.5 \mathrm{mg} / \mathrm{kg}$ and for zinc 0.3 $\mathrm{mg} / \mathrm{kg}$ b.w. to $1 \mathrm{mg} / \mathrm{kg}$ [26].

\subsection{Copper (Cu) Content}

$\mathrm{Cu}$ is an essential component in many enzymes, playing a significant role in a wide range of physiological processes including iron utilization, elimination of 
free radical, bone and connective tissue development, and many others disorders. Nevertheless, excessive intake of $\mathrm{Cu}$ can cause dermatitis, irritation of the upper respiratory tract, abdominal pain, nausea, diarrhea, vomiting, and liver damage [27].

The $\mathrm{Cu}$ concentrations recorded in the species $A$. spinosa from the coastal and mountain zones of the Maule Region, Chile (Table 3) indicate that the levels are higher than the ranges published by other authors in similar species [27] [28] [29] [30]. It should be noted that the highest concentrations of $\mathrm{Cu}$ in plant tissue were recorded in the samples from the coastal zone, although the soils in the coastal and cordillera zones present similar values (Figure 2(a)). The higher concentration of $\mathrm{Cu}$ in the coastal samples may possibly be explained by the fact that this zone is subjected to greater human activity due to its geographical location.

Statistical analysis of the results for $\mathrm{Cu}$ in the plant and soil samples indicated that significant differences existed between soil and plants from the Cordillera, but that this was not the case in the coastal samples. There were also no differences between plant and soil samples from different sites (Figure 2(a)).

The principal sources of $\mathrm{Cu}$ contamination are agrochemicals (pesticides and fertilizers), industrial waste, volcanic eruptions, foundries and ore-processing. $\mathrm{Cu}$ accumulates in the liver and brain, and is the main cause of Wilson's disease [31]. According to the World Health Organisation, the maximum permitted $\mathrm{Cu}$ content in medicinal plants is $10 \mathrm{mg} / \mathrm{kg}$, while maximum daily intake in foods is 2 - $3 \mathrm{mg} /$ day [20].

\subsection{Chromium (Cr) Content}

$\mathrm{Cr}$ is required for human physiological functions at an approximate concentration of $0.03 \mathrm{ppm}$, but its accumulation causes reduced blood glucose, alimentary and cardiovascular disorders, etc [27]. Cr is considered one of the most dangerous heavy metals for human health [25] [32], especially in its hexavalent form [33], which in high concentrations is toxic, mutagenic and carcinogenic [34] [35]. The main sources of $\mathrm{Cr}$ contamination include tanneries, wood impregnation plants, steel industries and wastewaters [36] [37]. The permissible limit of $\mathrm{Cr}$ in raw herbal material is $2.0 \mathrm{ppm}$, and that for finished products is 0.02 $\mathrm{mg} /$ day [27].

The $\mathrm{Cr}$ concentrations recorded in the $A$. spinosa samples from both the coastal and mountain zones of the Maule Region, Chile (Table 3), indicate that the levels are within the ranges published by other authors in similar species [29] [38]. The same is not the case with the $\mathrm{Cr}$ concentrations in the soil samples from the coastal and cordillera zones, whose mean values $(12.2$ and $29.4 \mathrm{mg} / \mathrm{kg}$ respectively), exceed those reported in other investigations [37] [38]. The higher $\mathrm{Cr}$ concentrations recorded in coastal soils as compared to cordillera samples may be attributable to farming and the use of certain fertilizers [39].

According to the data shown in Figure 2(b), the $\mathrm{Cr}$ concentrations presented 
significant differences in the soil and plant samples between the coastal and mountain zones; there are also statistical differences between the plant and the soil samples from the two zones. The explanation for the low incorporation of the $\mathrm{Cr}$ present in the soil into the plant may be that this element is present in the form of a chromate or dichromate (hexavalent chromium), whereas the soluble form consists of anionic species and not the cationic form like the majority of other metals. The presence of $\mathrm{Cr}$ in $A$. spinosa may be due to the trivalent $\mathrm{Cr}$ present in the medium. The maximum $\mathrm{Cr}$ content permitted by the WHO in medicinal plants is $1.5 \mathrm{mg} / \mathrm{kg}$, and the maximum daily ingestion is $0.2 \mathrm{mg}$ [19].

\subsection{Manganese (Mn) Content}

Manganese (Mn) is known as an essential trace element which acts as cofactor for many enzymes. It is less toxic than any other metal, however, can cause neurology disorders if its concentration exceeds $5 \mathrm{mg} / \mathrm{m}^{3}$ due to continuous exposure to manganese dust and fumes [40] [41].

In the present research, $\mathrm{Mn}$ was the element that presented the highest concentrations in both the plant and soil samples, from both the coastal and mountain zones (Table 3 ). The Mn concentrations in plants and soils exceed significantly the concentrations reported by other authors in similar species [29] [37] [38]. The high Mn concentrations in plants and soils are attributable to the fact that this element is an essential component of the mineral-bearing clays, which form one of principal constituents of the soil [23] [42] [43]. Mn is an essential element for plant and animal growth; however, above a certain concentration, it is highly dangerous for human beings, affecting both the lungs and the brain [44].

The statistical analysis presented in Figure 3(a) shows no significant differences in the Mn levels contained in soils and plants from the coastal and mountain zones. According to the World Health Organisation, the maximum permitted $\mathrm{Mn}$ content in medicinal plants is $200 \mathrm{mg} / \mathrm{kg}$, while the daily intake tolerated by the body is $11 \mathrm{mg} /$ day [19].

\subsection{Zinc (Zn) Content}

Zinc $(\mathrm{Zn})$ is an essential component of thousands of proteins in plants, although it is toxic in excess quantities ( $>10 \mathrm{ppm}$ ) [27], its accumulation causes gastrointestinal effects and anaemia.

The $\mathrm{Zn}$ concentrations recorded in the $A$. spinosa plants and associated soils from the coastal and mountain zones of the Maule Region, Chile (Table 3) indicate that the levels are within the ranges published by other authors in similar species [29] [38]. Zn plays a fundamental role in various enzymatic processes, as well as in DNA synthesis, brain development and bone formation [45].

The results presented in Figure 3(b) show significant differences in $\mathrm{Zn}$ content between plant and soil samples from the Cordillera, but not from the coastal zone. Significant differences were found between the soil samples from the two zones, but not between the plant samples. The maximum $\mathrm{Zn}$ concentration 
recommended by the WHO in medicinal plants is $50 \mathrm{mg} / \mathrm{kg}$, and the maximum daily intake is $11 \mathrm{mg} /$ day [46].

\section{Conclusions}

Medicinal plants are sources a large number of active principles of herbal and modern medicine. Chilean people use traditional medicine based in plants for years. Azorella is a native species from high Andes Mountain traditionally used to treat asthma, colds and bronchitis, illnesses with inflammation ar pain as the main symptoms. However, continuous increase in environmental pollution is leading to accumulation of these pollutants including toxic metals in the plant which eventually enter the human food chain [41].

In general, the species tested, used in traditional medicine or cosmetics and cosmetology, have different concentrations of toxic metals depending of area of collection [47]. Of the four metals studied in the present investigation $(\mathrm{Cu}, \mathrm{Cr}$, $\mathrm{Mn}$ and $\mathrm{Zn}$ ), Mn presented the highest concentrations in A. spinosa, in samples from both the coastal and mountain zones of the Maule Region, with mean values of $514 \mathrm{mg} / \mathrm{kg}$ in the coastal zone and $486 \mathrm{mg} / \mathrm{kg}$ in the Cordillera. These values exceed significantly the maximum levels permitted by the World Health Organisation (WHO) for medicinal plants $(200 \mathrm{mg} / \mathrm{kg}$ ), meaning that the use of A. spinosa is a potential danger to the health of consumers in the region. A lesser degree of health risk is presented by $\mathrm{Cu}$, with concentrations of 17.9 and 9.8 $\mathrm{mg} / \mathrm{kg}$ in samples of $A$. spinosa from the coastal and mountain zones respectively; the maximum allowed by WHO for medicinal plants is $10 \mathrm{mg} / \mathrm{kg}$. Finally, the concentrations of $\mathrm{Cr}$ and $\mathrm{Zn}$ recorded in the present investigation do not represent a health risk for consumers of $A$. spinosa.

\section{Acknowledgements}

The authors of the present investigation are grateful for PIEI QUIMBIO Project, Universidad de Talca, Chile.

\section{Conflicts of Interest}

The authors declare no conflict of interest regarding the publication of this paper.

\section{References}

[1] Martínez, J.L., Calvo, C.A. and Ladrido, C. (2006) Medicinal Plants Used in Chile for the Treatment of Hypertension and Mountain Sickness. African Journal of Traditional, Complementary and Alternative Medicines, 3, 50-58. https://doi.org/10.4314/ajtcam.v3i4.31171

[2] Torri, M.C. (2010) Medicinal Plants Used in Mapuche Traditional Medicine in Araucanía, Chile: Linking Sociocultural and Religious Values with Local Health Practices. Complementary Health Practice Review, 15, 132-148. https://doi.org/10.1177/1533210110391077

[3] Satorres, S.E., Chiaramello, A., Mattana, C.M., Alcaráz, L.E., Rossomando, P.C., Tonn, C. and Laciar, A.L. (2013) Azorella trifurcate and Mulinum echegarayii Ob- 
tained from Central Region of Argentina: Antibacterial Activity of Their Organic Extracts. Emirates Journal of Food and Agriculture, 25, 457-462.

https://doi.org/10.9755/ejfa.v25i6.15554

[4] WHO (World Health Organization) (2002) Traditional Medicine Strategy (2002-2005). Geneva.

[5] Chan, K. (2003) Some Aspects of Toxic Contaminants in Herbal Medicines. Chemosphere, 52, 1361-1371. https://doi.org/10.1016/S0045-6535(03)00471-5

[6] Dghaim, R., Al Khatib, S., Rasool, H. and Ali Khan, M. (2015) Determination of Heavy Metals Concentration in Traditional Herbs Commonly Consumed in the United Arab Emirates. Journal of Environmental and Public Health, 2015, Article ID: 973878. https://doi.org/10.1155/2015/973878

[7] Fabricant, D.S. and Farnsworth, N.R. (2001) The Value of Plants Used in Traditional Medicine for Drug Discovery. Environmental Health Perspectives, 109, 69-75. https://doi.org/10.1289/ehp.01109s169

[8] Saad, B., Azaizeh, H., Abu-Hijleh, G. and Said, O. (2006) Safety of Traditional Arab Herbal Medicines. Evidence-Based Complementary and Alternative Medicine, 3, 433-439. https://doi.org/10.1093/ecam/nel058

[9] Jaishankar, M., Tseten, T., Anbalagan, N., Mathew, B.B. and Beeregowda, K.N. (2014) Toxicity, Mechanism and Health Effects of Some Heavy Metals. Interdisciplinary Toxicology, 7, 60-72. https://doi.org/10.2478/intox-2014-0009

[10] Singh, R., Gautam, N., Mishra, A. and Gupta, R. (2011) Heavy Metals and Living Systems: An Overview. Indian Journal of Pharmacology, 43, 246-253. https://doi.org/10.4103/0253-7613.81505

[11] Korfali, S.I., Hawi, T. and Mroueh, M. (2013) Evaluation of Heavy Metals Content in Dietary Supplements in Lebanon. Chemistry Central Journal, 7, 10. https://doi.org/10.1186/1752-153X-7-10

[12] Korfali, S.I., Mroueh, M., Al-Zein, M. and Salem, R. (2013) Metal Concentration in Commonly Used Medicinal Herbs and Infusion by Lebanese Population: Health Impact. Journal of Food Research, 2, 70-80. https://doi.org/10.5539/jfr.v2n2p70

[13] Alwakeel, S.S. (2008) Microbial and Heavy Metals Contamination of Herbal Medicines. Research Journal of Microbiology, 3, 683-691. https://doi.org/10.3923/jm.2008.683.691

[14] Harris, E.S.J., Cao, S., Littlefield, B.A., Craycroft, J.A., Scholten, R., Kaptchuk, T., Fu, Y., Wang, W., Liu, Y., Chen, H., Zhao, Z., Clardy, J., Woolf, A. and Eisenberg, D.M. (2011) Heavy Metal and Pesticide Content in Commonly Prescribed Individual Raw Chinese Herbal Medicines. Science of the Total Environment, 409, 4297-4305. https://doi.org/10.1016/j.scitotenv.2011.07.032

[15] Saeed, M., Muhammad, N. and Khan, H. (2011) Assessment of Heavy Metal Content of Branded Pakistani Herbal Products. Tropical Journal of Pharmaceutical Research, 10, 499-506. https://doi.org/10.4314/tjpr.v10i4.16

[16] Wickens, G.E. (1995) Llareta (Azorella compacta, Umbelliferae): A Review. Economic Botany, 49, 207-212. https://doi.org/10.1007/BF02862926

[17] Molina-Salinas, G.M., Bórquez, J., Said-Fernández, S., Loyola, L.A., Yam-Puc, A., Becerril-Montes, P., Escalante-Erosa, F. and Peña-Rodríguez, L.M. (2010) Antituberculosis Activity of Alkylated Mulinanediterpenoids. Fitoterapia, 81, 219-222. https://doi.org/10.1016/j.fitote.2009.09.006

[18] San Martín, A., Bacho, M., Cretton, S., Christen, P., Olea, A., Muñoz, D., Guillen, A. and Balcazar, N. (2016) Evaluation of the Hypoglycemic Effects of Extracts and Di- 
terpenoids from Azorella compacta (llareta). Planta Medica, 82, S1-S381. https://doi.org/10.1055/s-0036-1596506

[19] WHO (World Health Organization) (1998) Quality Control Methods for Medicinal Plant Materials. Geneva.

[20] WHO (World Health Organization) (2005) Quality Control Methods for Medicinal Plant Materials. Geneva.

[21] Walinga, I., Van der Lee, J.J., Houba, V.J.G., Van Vark, W. and Novozamsky, I. (1995) Plant Analysis Manual. Kluwer Academia Publishers, Dordrecht. https://doi.org/10.1007/978-94-011-0203-2

[22] Kalra, Y.P. (1998) Handbook of Reference Methods for Plant Analysis. CRC Press, Boca Raton. https://doi.org/10.1201/9781420049398

[23] Tapia, J., Vargas-Chacoff, L., Bertran, C., Peña-Cortés, F., Hauenstein, E., Schlatter, R., Valderrama, A., Lizana, C. and Fierro, P. (2014) Accumulation of Potentially Toxic Elements in Sediments in Budi Lagoon, Araucania Region, Chile. Environmental Earth Sciences, 72, 4283-4290. https://doi.org/10.1007/s12665-014-3324-4

[24] Pereira, I., Tapia, J., Errázuriz, I. and Basualto, S. (2018) Comparative Study of the Presence of Heavy Metals Utilizing Epiphytic Corticolous Lichens in Talca City, Maule Region, Chile. Gayana Botanica, 75, 494-500. https://doi.org/10.4067/S0717-66432018000100494

[25] Tapia, J., Vargas-Chacoff, L., Bertrán, C., Carrasco, G., Torres, F., Pinto, R., Urzúa, S., Valderrama, A. and Letelier, L. (2010) Study of the Content Cadmium, Chromium and Lead in Bivalve Molluscs of the Pacific Ocean (Maule Region, Chile). Food Chemistry, 121, 666-671. https://doi.org/10.1016/j.foodchem.2009.12.091

[26] Pugh, R., Dick, D. and Fredeen, A. (2002) Heavy Metal (Pb, Zn, Cd, Fe, and Cu) Contents of Plant Foliage near the Anvil Range Lead/Zinc Mine, Faro, Yukon Territory. Ecotoxicology and Environmental Safety, 52, 273-279.

https://doi.org/10.1006/eesa.2002.2201

[27] Kohzadi, S., Shahmoradi, B., Ghaderi, E., Loqmani, H. and Maleki, A. (2018) Concentration, Source, and Potential Human Health Risk of Heavy Metals in the Commonly Consumed Medicinal Plants. Biological Trace Element Research, 187, 41-50. https://doi.org/10.1007/s12011-018-1357-3

[28] Wu, J., Tan, Y., Wang, Y. and Xu, R. (2011) Toxic Metal Contamination in Artemisia annua L. Herbal Preparations from Different Commercial Sources in China. Journal of Natural Medicines, 65, 656-661. https://doi.org/10.1007/s11418-011-0511-4

[29] Ebrahim, A., Eltayeb, M., Khalid, H., Mohamed, H., Abadía, W., Grill, P. and Michalke, B. (2012) Study on Selected Trace Elements and Heavy Metals in Some Popular Medicinal Plants from Sudan. Journal of Natural Medicines, 66, 671-679. https://doi.org/10.1007/s11418-012-0630-6

[30] Kozak, L., Kokocinski, M., Niedzielski, P. and Lorenc, S. (2014) Bioaccumulation of Metals and Metalloids in Medicinal Plant Ipomoea pes-caprae from Areas Impacted by Tsunami. Environmental Toxicology and Chemistry, 34, 252-257. https://doi.org/10.1002/etc.2794

[31] Nazir, R., Khan, M., Masab, M., Rehman, H., Rauf, N., Shahab, S., Ameer, N., Sajed, M., Ullah, M., Rafeeq, M. and Shaheen, Z. (2015) Accumulation of Heavy Metals $(\mathrm{Ni}, \mathrm{Cu}, \mathrm{Cd}, \mathrm{Cr}, \mathrm{Pb}, \mathrm{Zn}, \mathrm{Fe})$ in the Soil, Water and Plants and Analysis of Physico-Chemical Parameters of Soil and Water Collected from Tanda Dam Kohat. Journal of Pharmaceutical Sciences and Research, 7, 89-97. 
[32] USFDA (1993) Food and Drug Administration, Guidance Document for Chromium in Shellfish. DHHS/PHS/FDA/ CFSAN/Office of Seafood, Washington DC, 40.

[33] World Health Organization (1988) Environmental Health, Criteria 61 Chromium. Geneva.

[34] Nriega, J.O. and Nieboer, E. (1988) Chromium in the Natural and Human Environmental. Wiley, New York.

[35] Chishti, K.A., Khan, F.A., Hassan, S.S.M., Asif, S.A., Khan, J.K., Mukarram, S.M. and Hussain, S.I. (2011) Estimation of Heavy Metals in the Seeds of Blue and Whitecapitulum's of Silybum marianum Grown in Various Districts of Pakistan. Journal of Basic and Applied Sciences, 7, 45-49.

[36] Bruhn, C., Villablanca, L., Campos, V., Basualto, S. and Tapia, J. (1997) Determination of Cr (III) and Cr (VI) in Water by Flow Injection On-Line Precontration Flame Atomic Absorption Spectrometry. Boletin de la Sociedad Chilena de Quimica, 42, 83-99.

[37] Hussain, I. and Khan, H. (2010) Investigation of Heavy Metals Content in Medicinal Plant, Eclipta alba L. Journal of the Chemical Society of Pakistan, 32, 28-33.

[38] Shah, A., Niaz, A., Ullah, N., Rehman, A., Akhlaq, M., Zakir, M. and Khan, M. (2013) Comparative Study of Heavy Metals in Soil and Selected Medicinal Plants. Journal of Chemistry, 2013, Article ID: 621265. https://doi.org/10.1155/2013/621265

[39] Galvao, L. and Corey, G. (1987) Cromo. Centro Panamericano de Ecología Humana Salud, Organización Panamericana de la Salud. Organización Mundial de la Salud. Metepec: México, Serie Vigilancia No. 5.

[40] Santamaria, A.B. (2008) Manganese Exposure, Essentiality \& Toxicity. Indian Journal of Medical Research, 128, 484-500.

[41] Kulhari, A., Sheorayan, A., Bajar, S., Sarkar, S., Chaudhury, A. and Kalia, R.(2013) Investigation of Heavy Metals in Frequently Utilized Medicinal Plants Collected from Environmentally Diverse Locations of North Western India. SpringerPlus, 2, 676. https://doi.org/10.1186/2193-1801-2-676

[42] Carrol, P. (1958) Role of Clay Minerals in Transportation of Iron. Geochimica et Cosmochimica Acta, 3, 9-60. https://doi.org/10.1016/0016-7037(58)90090-5

[43] Hamed, M.A. (1998) Distribution of Trace Metals in the River Nile Ecosystem, Damietta Branch between Mansoura City and Damietta Province. Journal of the Egyptian-German Society of Zoology, 27, 399-415.

[44] Järup, L. (2003) Hazards of Heavy Metal Contamination. British Medical Bulletin, 68, 167-182. https://doi.org/10.1093/bmb/ldg032

[45] Adelekan, B.A. and Abegunde, K.D. (2011) Heavy Metals Contamination of Soil and Groundwater at Automobile Mechanic Villages in Ibadan, Nigeria. International Journal of Physical Sciences, 6, 1045-1058.

[46] Khan, S.A., Khan, L., Hussain, I., Marwat, K.B. and Akhtar, N. (2008) Profile of Heavy Metals in Selected Medicinal Plants. Pakistan Journal of Weed Science Research, 14, 101-110.

[47] Fischer, A., Brodziak-Dopierała, B., Krzysztof Loska, K. and Stojko, J. (2017) The Assessment of Toxic Metals in Plants Used in Cosmetics and Cosmetology. International Journal of Environmental Research and Public Health, 14, 1280. https://doi.org/10.3390/ijerph14101280 